\title{
Article \\ Electrifying with High-Temperature Water Electrolysis to Produce Syngas from Wood via Oxy-Gasification, Leading to Superior Carbon Conversion Yield for Methanol Synthesis
}

\author{
Sylvain Larose $^{1, *}$, Raynald Labrecque ${ }^{2}$ and Patrice Mangin ${ }^{1}$ \\ 1 Innovations Institute in Ecomaterials, Ecoproducts, and Ecoenergies, Université du Québec à Trois-Rivières, \\ Trois-Rivières, QC G9A 5H7, Canada; Patrice.Mangin@uqtr.ca \\ 2 Energy Technology Laboratory, Hydro-Quebec Research Center, Shawinigan, QC G9N 6T6, Canada; \\ Labrecque.Raynald@hydroquebec.com \\ * Correspondence: Sylvain.Larose@uqtr.ca
}

check for updates

Citation: Larose, S.; Labrecque, R.; Mangin, P. Electrifying with HighTemperature Water Electrolysis to Produce Syngas from Wood via Oxy-Gasification, Leading to Superior Carbon Conversion Yield for Methanol Synthesis. Appl. Sci. 2021, 11, 2672. https://doi.org/10.3390/ app11062672

Academic Editor: Mariya Marinova

Received: 6 December 2020

Accepted: 5 March 2021

Published: 17 March 2021

Publisher's Note: MDPI stays neutral with regard to jurisdictional claims in published maps and institutional affiliations.

Copyright: (c) 2021 by the authors. Licensee MDPI, Basel, Switzerland. This article is an open access article distributed under the terms and conditions of the Creative Commons Attribution (CC BY) license (https:/ / creativecommons.org/licenses/by/ $4.0 /)$.

\begin{abstract}
Due to concerns regarding fossil greenhouse gas emissions, biogenic material such as forest residues is viewed nowadays as a valuable source of carbon atoms to produce syngas that can be used to synthesise biofuels such as methanol. A great challenge in using gasified biomass for methanol production is the large excess of carbon in the syngas, as compared to the $\mathrm{H}_{2}$ content. The water-gas shift (WGS) reaction is often used to add $\mathrm{H}_{2}$ and balance the syngas. $\mathrm{CO}_{2}$ is also produced by this reaction. Some of the $\mathrm{CO}_{2}$ has to be removed from the gaseous mixture, thus decreasing the process carbon yield and maintaining $\mathrm{CO}_{2}$ emissions. The WGS reaction also decreases the overall process heat output. This paper demonstrates the usefulness of using an extra source of renewable $\mathrm{H}_{2}$ from steam electrolysis instead of relying on the WGS reaction, for a much higher performance of syngas production from gasification of wood in a simple system with a fixed-bed gasifier. A commercial process simulation software is employed to predict that this approach will be more efficient (overall energy efficiency of about $67 \%$ ) and productive (carbon conversion yield of about $75 \%$ ) than relying on the WGS reaction. The outlook for this process that includes the use of the solid oxide electrolyser technology appears to be very promising because the electrolyser has the dual function of providing all of the supplemental $\mathrm{H}_{2}$ required for syngas balancing and all the $\mathrm{O}_{2}$ required for the production of a suitable hot raw syngas. This process is conducive to biomethanol production in dispersed, small plants using local biomass for end-users from the same geographical area, thus contributing to regional sustainability.
\end{abstract}

Keywords: biomass gasification; methanol production; solid oxide electrolysis; regional sustainability; electrification; carbon yield

\section{Introduction}

Synthesis gas, commonly referred to as syngas, is a mixture that contains mainly hydrogen $\left(\mathrm{H}_{2}\right)$, carbon monoxide $(\mathrm{CO})$, and some carbon dioxide $\left(\mathrm{CO}_{2}\right)$. When derived from solid fuels such as coal or wood, syngas may also be called producer gas. Syngas is used for the production of a broad range of products, namely, hydrocarbon fuels such as gasoline, diesel, or commodity chemicals such as methanol. Methanol is a versatile molecule. This alcohol is a basic commodity chemical used as a solvent, a starting material for a large spectrum of chemicals, and a liquid fuel that can be safely handled and stored. In addition, methanol can easily be converted into dimethyl ether (DME), another basic chemical widely viewed as a substitute for diesel in internal compression engines.

From the mid-19th century up until the early 20th century, methanol was produced commercially through destructive wood distillation, which was a pyrolysis process conducted in a distillation apparatus to separate the products [1]. In 1923, the German BASF company started producing methanol, using fossil fuel derived $\mathrm{H}_{2}, \mathrm{CO}$, and $\mathrm{CO}_{2}$ as reac- 
tant syngas. A catalytic, high-pressure synthesis of methanol was then achieved. Methanol $\left(\mathrm{CH}_{3} \mathrm{OH}\right)$ production is characterised by the well-known reaction as follows:

$$
\mathrm{CO}+2 \mathrm{H}_{2} \rightarrow \mathrm{CH}_{3} \mathrm{OH}
$$

For this reaction, an ideal syngas should be a mixture of $\mathrm{H}_{2}$ and $\mathrm{CO}$ with a molar $\mathrm{H}_{2} / \mathrm{CO}$ ratio of 2. As mentioned earlier, syngas always contains some $\mathrm{CO}_{2}$ which can contribute to methanol formation, alongside water $\left(\mathrm{H}_{2} \mathrm{O}\right)$, according to the following reaction:

$$
\mathrm{CO}_{2}+3 \mathrm{H}_{2} \rightarrow \mathrm{CH}_{3} \mathrm{OH}+\mathrm{H}_{2} \mathrm{O}
$$

In order to consider the amount of $\mathrm{CO}_{2}$ that a given syngas may contain, and according to Reactions (1) and (2), the most widely used criteria for methanol synthesis is the following molar concentration balance ratio:

$$
\mathrm{M}=\left(\mathrm{H}_{2}-\mathrm{CO}_{2}\right) /\left(\mathrm{CO}+\mathrm{CO}_{2}\right)=2
$$

Because of concerns regarding fossil greenhouse gas emissions, biogenic materials such as forest residues are nowadays considered as a valuable source of carbon atoms to produce syngas. When biomass is used as a feedstock for the production of methanol, gasification with pure oxygen $\left(\mathrm{O}_{2}\right)$ and steam is widely considered as a well-suited technology for the production of syngas. Due to its intrinsic atomic composition, woody biomass cannot directly produce syngas with a molar composition that satisfies the Equation (3) criterion. Generally, gas at the outlet of a gasifier will present an $\mathrm{M}$ number closer or even less than 1. In effect, with steam gasification of carbon from biomass, only one $\mathrm{H}_{2}$ molecule is generated alongside each $\mathrm{CO}$ molecule in the following illustrative reaction:

$$
\mathrm{C}+\mathrm{H}_{2} \mathrm{O} \rightarrow \mathrm{CO}+\mathrm{H}_{2}
$$

In order to obtain a particular syngas according to the criterion of Equation (3), composition adjustment or "balancing" of raw gas from a gasifier is required. Syngas balancing usually involves the use of the well-known water-gas shift (WGS) reaction as follows:

$$
\mathrm{CO}+\mathrm{H}_{2} \mathrm{O} \rightarrow \mathrm{CO}_{2}+\mathrm{H}_{2}
$$

This reaction leads to the production of extra $\mathrm{H}_{2}$, but at the expense of a loss of $\mathrm{CO}$. Extra $\mathrm{CO}_{2}$ is produced, and must be separated and wasted, thus decreasing significantly the efficiency of carbon conversion into $\mathrm{CO}$. In other words, a significant amount of carbon is lost, meaning a net decrease in carbon conversion yield.

Theoretically, starting from Reaction (4), in order to obtain an $\mathrm{H}_{2} / \mathrm{CO}$ ratio of 2 for a given syngas, $1 / 3$ of a mole of $\mathrm{CO}$ must react according to Reaction (5), producing $1 / 3$ of a mole of $\mathrm{CO}_{2}$ in the process. The theoretical carbon conversion yield is then $66.7 \%$. In practice, the real, verified carbon conversion yield is lower than $60 \%$ when this WGS approach is taken.

It has been stated that the greatest challenge in using gasified biomass for methanol production lies in the large excess of carbon in the syngas [2]. An option to deal with this issue consists of using an acid-gas separation process to remove $\mathrm{CO}_{2}$ from the syngas until the correct balance ratio is reached. Another approach to obtain this ratio is to add $\mathrm{H}_{2}$ to the syngas. The endothermal WGS reaction can be used for this purpose. Alongside $\mathrm{H}_{2}, \mathrm{CO}_{2}$ is also formed by the reaction. Some of this $\mathrm{CO}_{2}$ has to be removed from the gaseous mixture, decreasing the process carbon yield and maintaining $\mathrm{CO}_{2}$ emissions, even though the carbon released is of biogenic origin. The WGS reaction also affects the overall process heat output negatively. An alternative source of $\mathrm{H}_{2}$ would be from an electrolyser. If the electricity consumed by the electrolyser comes from a renewable source, such as hydropower, then the process remains carbon-neutral, meaning that it does not require the use of fossil carbon. In addition, hydropower is usually much cheaper than power 
generated by other renewable means. Areas of the world where biomass and hydropower are readily available are ideally suited to biomethanol production.

Ali et al. modeled a system made of a wheat straw fueled, low temperature circulating fluidised bed and a high-temperature solid oxide electrolyser (SOE) to synthesise methanol with high energy efficiency and high carbon conversion yield [3]. They explained that the SOE requires less electrical energy, compared to lower temperature electrolysis technologies. They stated that the extra heat required for the endothermal SOE reaction, compared to other technologies, can easily be provided by the gasification reactions. They mentioned the usefulness of having a general match between the $\mathrm{SOE}$ operating temperature and the gasification temperatures. They showed that the SOE generates separate streams of $\mathrm{O}_{2}$ and $\mathrm{H}_{2}$ that can both be used advantageously. The $\mathrm{O}_{2}$ can be used as a gasifying agent to enhance energy efficiency. The $\mathrm{H}_{2}$ can be used to boost methanol production.

Precise prediction of gasification product characteristics (e.g., product distribution, chemical composition, and energy content) and process variables is very challenging. Some research has been directed towards improving such predictions for the purpose of optimizing operation conditions, such as in a downdraft gasifier [4]. Some modelling studies have been conducted on the simulation of more complex systems, such as a technology that included an entrained flow gasifier [5]. Artificial intelligence has been applied with the objective of obtaining more accurate predictions for the thermal properties of biomass [6]. The present article is not devoted to obtaining simulation results that provide the most precise possible predictions, at a level that would be required, for example, for industrial design and specifications. Through simple, basic modelling, the purpose of the current paper is to show the potential and introduce a new integrated system concept.

This article aims at briefly presenting and demonstrating the usefulness of using an extra source of renewable $\mathrm{H}_{2}$ instead of relying on the WGS reaction, for a much higher performance of syngas production from gasification of wood in a simple system that includes a fixed-bed gasifier. With the use of a process simulation program, we demonstrate the usefulness of a judicious integration of high-temperature water electrolysis, for a drastic increase in carbon conversion yield. A general process concept is exposed in the form of simple mathematical blocks, relying on mass and energy balance, stoichiometry, and thermodynamics. This process is conducive to biomethanol production in dispersed, small plants using local biomass for end-users from the same geographical area, thus contributing to regional sustainability.

\section{Method}

In this paper, we suggest a process to synthesise methanol from ligneous biomass, but with the aid of green electricity. In that sense, this paper describes a renewed, yet original, wood-based, highly efficient, sustainable approach to generate syngas to be used for synthesising methanol since this alcohol was originally produced commercially from wood gasification and distillation.

\subsection{Conceptual Process}

The conceptual process is schematically presented in Figure 1. This concept is suggested to produce syngas in small methanol plants. Wood pellets are suggested as feedstock for the process. Raw syngas from wood contains less nitrogen oxides (NOx) and sulphur dioxide $\left(\mathrm{SO}_{2}\right)$ than fossil fuels, making this syngas more suitable than these fossil fuels for fuel refining. Pellets can easily be produced nearby as a local bioresource and then transported to a small plant. Wood pellets represent a choice feedstock, being homogeneous (or quasi-homogeneous) in terms of composition, sizing, dryness, and ash and impurity content. The system capacity, or mass flow of ash-free, dry biomass feed, is set at $1000 \mathrm{~kg} / \mathrm{h}$. 


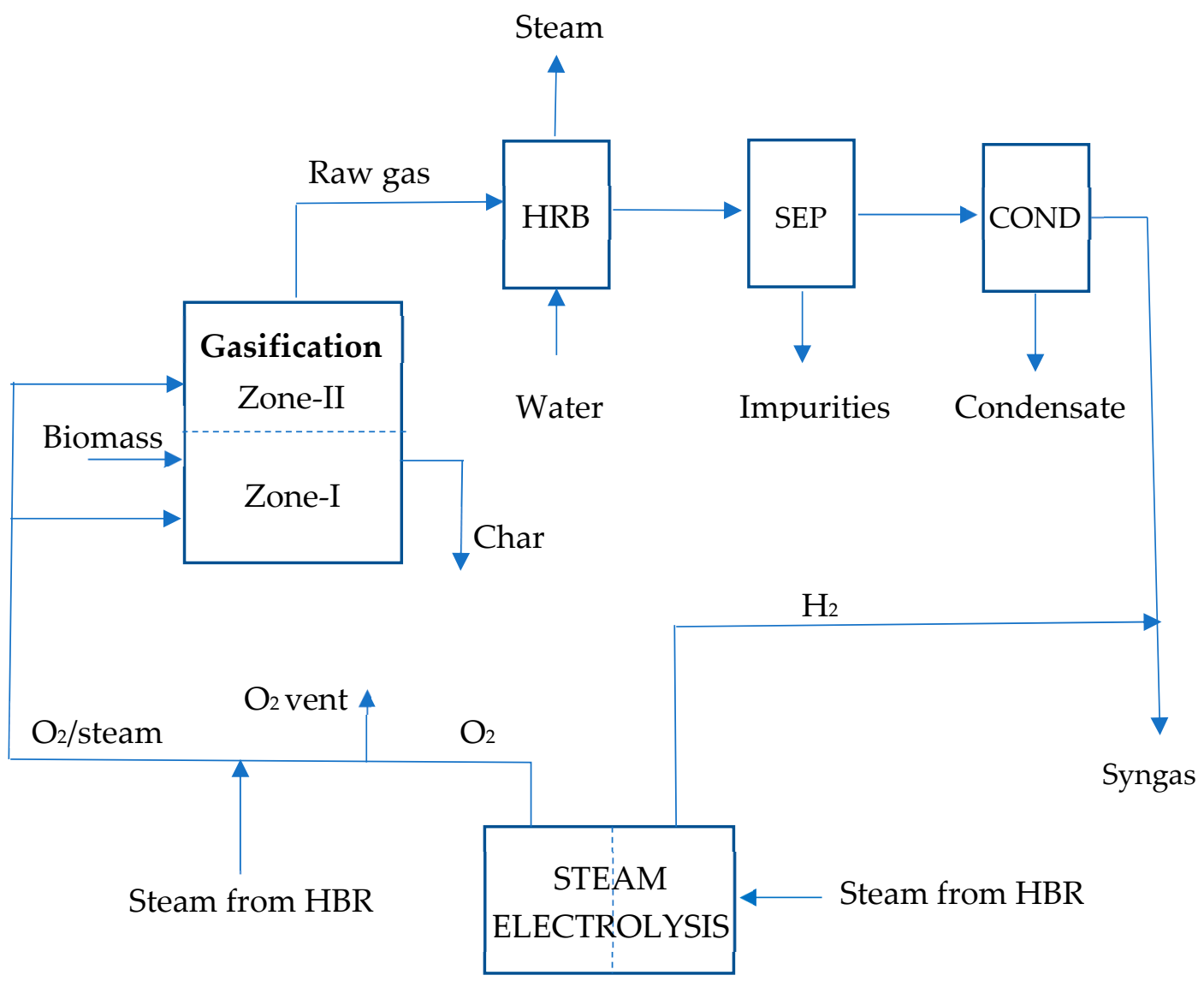

Figure 1. Schematic block diagram of a conceptual integration of water electrolysis with biomass gasification.

As shown in Figure 1, biomass is fed into a gasifier to produce syngas. The updraft fixed bed configuration was chosen as a convenient technology. The working principles of the updraft gasifier are illustrated in Figure 2. In the reactor, gasifying agent air or $\mathrm{O}_{2}$ is inserted at the bottom and flows upward to generate producer gas. At the same time, biomass in the form of wood pellets is inserted at the top and moves downward through zones in which drying, pyrolysis, gasification, and oxidation occur stepwise. The temperature increases roughly from $200^{\circ} \mathrm{C}$ in the drying area to $100{ }^{\circ} \mathrm{C}$ in the oxidation area. This type of gasifier is selected because it offers key advantages for the intended application. The design and operation are simple. The producer gas from this gasifier contains light gases such as $\mathrm{CO}, \mathrm{H}_{2}, \mathrm{CO}_{2}, \mathrm{H}_{2} \mathrm{O}$, and methane $\left(\mathrm{CH}_{4}\right)$, and tars that are in large part oxygenated, containing molecules such as anisole $\left(\mathrm{C}_{7} \mathrm{H}_{8} \mathrm{O}\right)$ [7-9]. These tars are easily thermally converted into simple molecules such as $\mathrm{H}_{2}$ and $\mathrm{CO}$. Complete conversion of oxygenated tars from updraft gasifiers was demonstrated [10]. In a downdraft gasifier, on the other hand, tars are made practically entirely of non-oxygenated molecules, such as aromatics such as benzene $\left(\mathrm{C}_{6} \mathrm{H}_{6}\right)$ [11]. The latter do not convert as readily into simpler gaseous molecules. They require adding a considerable amount of steam to decrease cocking on surfaces downstream. The system energy efficiency is then reduced because of the heat required to generate and heat up steam, in addition to the highly endothermal nature of the steam reforming reaction. For example, these non-oxygenated tars can lead to cocking of the catalyst for methanol synthesis, thus reducing its activity. Residual aromatics such as benzene and toluene also represent a human health hazard. Fluidised bed gasifiers generate a mix of oxygenated and non-oxygenated tars, bringing still similar issues as with the downdraft configuration [12]. 


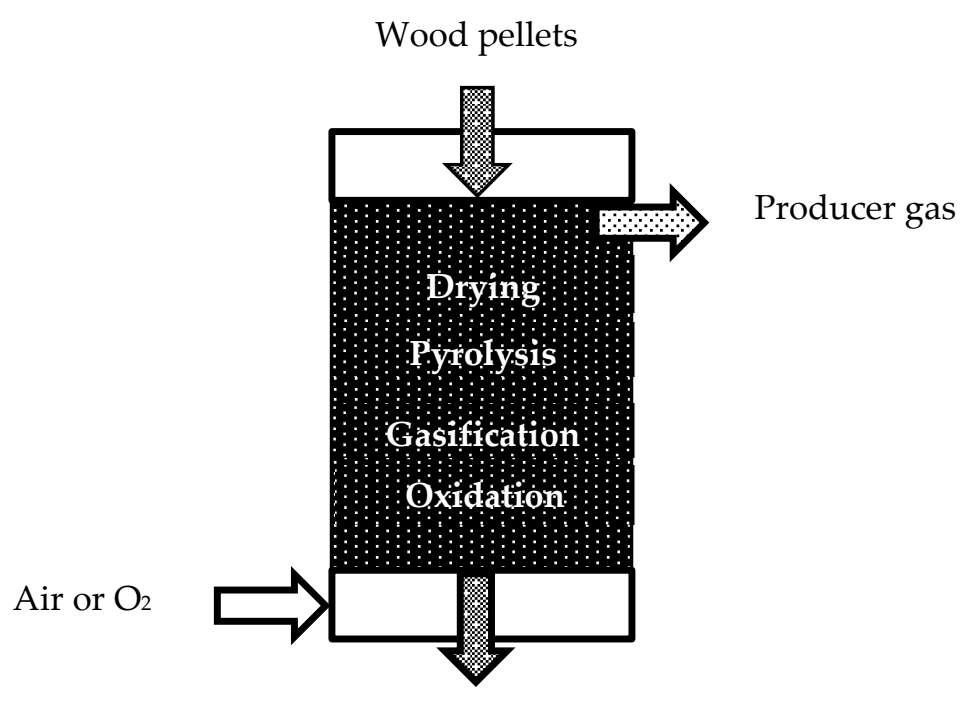

Ash

Figure 2. Schematic diagram of an updraft gasifier with flow patterns for gases and solids.

When dealing with small plants, fluidised bed gasifiers also have higher manufacturing costs, and are trickier to operate and maintain, compared to fixed bed gasifiers. The fact that oxygenated tars from the updraft gasifier react easily precludes the need of adding large quantities of steam or separating these tars for disposal. The energy content of these tars is then preserved in the syngas as sensible heat or heating value of tar decomposition products. The process carbon yield is kept higher as a result. Updraft gasifiers are also known for their durability. A commercial unit fueled with wood chips was operated for more than $120,000 \mathrm{~h} \mathrm{[13].}$

Even though tars generated in the updraft gasifier react at a lower temperature compared to tars from other gasifiers, they exit the reactor in a zone that is too cold for them to react. The raw syngas needs to be heated up to a higher temperature after exiting the conventional reactor area, meaning after passing through the drying zone.

The gasifier is divided into two zones, as shown in Figure 1. Combustion (oxidation) and hydro-pyrolysis (thermal degradation and reaction with steam) of the biomass take place in Zone-I, which represents a typical gasifier as the one depicted in Figure 2. In this zone, $\mathrm{O}_{2}$ with some steam is injected. If air were used as gasifying agent, large amounts of nitrogen $\left(\mathrm{N}_{2}\right)$ would have to be heated up, decreasing energy efficiency. Additionally, this $\mathrm{N}_{2}$ would have to be removed from the gaseous mixture prior to synthesizing methanol. Using pure $\mathrm{O}_{2}$ instead of air means less sensible heat has to be provided for the process.

Products from Zone-I include gaseous components, tars, and a carbonaceous solid called char that contains the ashes. We consider that gaseous components may include, in addition to $\mathrm{H}_{2}, \mathrm{CO}, \mathrm{CO}_{2}$, and steam, some hydrocarbons (namely $\mathrm{CH}_{4}$ ), and some nitrogenand sulphur-based impurities [7]. The char is recovered and separated from Zone-I. The gasifier must be designed and operated in such a way that most of the solids and particles out from the pyrolysis process end up in the char. The gaseous components flow into Zone-II of the gasifier. In this zone, $\mathrm{O}_{2}$ and some steam are again injected. The purpose of injecting $\mathrm{O}_{2}$ is to increase the temperature (up to $\sim 1200{ }^{\circ} \mathrm{C}$ ) of the gaseous mixture through its very incomplete combustion, while steam allows for steam reforming of tars and hydrocarbons into small molecules such as $\mathrm{H}_{2}, \mathrm{CO}$, and $\mathrm{CO}_{2}$. As was explained for the gasifier inlet, injecting pure $\mathrm{O}_{2}$ instead of air in Zone-II also leads to higher energy efficiency. Moreover, oxygenated tars typically require a low $\mathrm{O}_{2}$ to fuel ratio for complete reaction, compared to aromatics-containing tars. The gas exiting the gasifier is expected to be tar-free and with most of its hydrocarbons thermally reformed. This type of process can be referred to as partial oxidation (POX) of producer gas. 
At the exit of Zone-II, the gaseous mixture is referred to as a "hot raw syngas." This mixture is fed into a heat recovery steam boiler (HRB), where the gas is rapidly cooled down to $150{ }^{\circ} \mathrm{C}$ while producing low-pressure steam. At the exit of the recovery boiler, impurities such as sulphur components are separated. We consider this separation step (SEP) to be realised through a physical adsorption process (e.g., using zinc oxide ( $\mathrm{ZnO})$ as an adsorbent). The required impurity removal rate is expected to be very low, considering that the biomass feed contains very low amounts of sulphur and other impurities.

The gas is then fed into a water-condensing unit (COND), where it is dehumidified while recovering water as a condensate. At the exit of the condensing unit, the syngas has not yet been balanced. This balancing is achieved through mixing with electrolytic $\mathrm{H}_{2}$ in order to have suitable syngas that fulfills the criteria of Equation (3).

As shown in Figure 1, required electrolytic $\mathrm{H}_{2}$ comes from a water (steam) electrolysis system (ELECTROLYSIS). This system must be specified to generate the amount of $\mathrm{H}_{2}$ required for the process. Water electrolysis involves the co-production of $\mathrm{O}_{2}$ as follows:

$$
\mathrm{H}_{2} \mathrm{O} \rightarrow \mathrm{H}_{2}+1 / 2 \mathrm{O}_{2}
$$

The quantity of coproduced $\mathrm{O}_{2}$ is expected to exceed the amount of pure $\mathrm{O}_{2}$ required for the gasification process. Part of the produced $\mathrm{O}_{2}$ is vented or stored. The other part is mixed with steam. The mixture $\left(\mathrm{O}_{2} /\right.$ steam) is split into two streams-the first one is injected in Zone-I, while the second one is injected in Zone-II of the gasifier.

Essentially, with the process concept hereby presented, the electrolysis system can be considered as a utility device supplying both $\mathrm{H}_{2}$ and $\mathrm{O}_{2}$. This dual function makes the process independent of the type of electrolyser chosen. In principle, either an alkaline, a polymer electrolyte membrane, or even a solid oxide electrolyser (a less mature technology) could be used. The principle of operation of a solid oxide electrolysis cell (SOEC) device can be considered to be the reverse of that of a solid oxide fuel cell (SOFC). SOEC systems require a supply of steam, electrical power, and absorbed heat to carry out the electrolysis process. Since the system operates at high temperatures, the electrical power required is less than that of electrolysers operating at lower temperatures, due to the fact that the variation in free energy between reactant and products is smaller, as is the overvoltage during operation [14]. The amount of electrical energy required could be 35\% less than that which is required by alkaline electrolysers for the same amount of $\mathrm{H}_{2}$ produced. The amount of heat absorbed by the process is a little higher than that of low-temperature processes, again for thermodynamic reasons. However, when integrated with a biorefinery plant, it would be possible to recover and use both the heat and the steam released by the gasification process as a feed for the high-temperature electrolyser. In addition, the decreased intensity of heat released into the environment would be a positive factor. The heat generated by the Joule effect within the electrolysis cells is also used for the endothermic reaction. The all-solid phase constitution of SOECs ensures that liquid corrosion problems in alkaline electrolysers are avoided, in addition to problems of degradation of membranes in polymer electrolyte membrane (PEM) electrolysers. Moreover, the SOEC high operating temperature means that the reaction kinetics are faster, thus avoiding the need for expensive catalysts such as platinum that is used in PEM electrolysers. In addition, the lifespan of solid oxide stacks is known to be longer than that of polymer membrane stacks. For these reasons, for the purpose of this article, we selected the solid oxide electrolyser as a well-suited technology.

\subsection{Model for Simulations}

Figure 3 shows the mathematical blocks for the calculation of mass and energy balance of the conceptual process described above. CHEMCAD (v. 7.1, Chemstations Inc., Houston, TX, USA) chemical process simulator was used. Dry, ash-free, biomass feedstock is characterised by the empirical molecular form $\mathrm{C}_{\alpha} \mathrm{H}_{\beta} \mathrm{O}_{\gamma} \mathrm{N}_{\psi} \mathrm{S}_{\varepsilon}$. This feedstock is considered to be combustion solid with a lower heating value (LHV) of $20 \mathrm{MJ}$ per $\mathrm{kg}$ of dry, ash-free biomass. The assumption is made that the humidity content of the biomass is $5 \%$ on a dry, ash-free 
basis and that it contains $0.5 \%$ of inert, inorganic material on a dry, ash-free basis. A flow of $1000 \mathrm{~kg} / \mathrm{h}$ of ash-free, dry biomass is fed into Zone-I of the gasifier, along with its water and ash content. The biomass stream BIOM shown in Figure 3 is considered to contain dry, ash-free biomass along with humidity and some inorganic material. This inorganic material is considered inert. For the purpose of calculation, the following reactions are considered for Zone-I of the gasifier:

$$
\begin{aligned}
& \mathrm{C}_{\alpha} \mathrm{H}_{\beta} \mathrm{O}_{\gamma} \mathrm{N}_{\psi} \mathrm{S}_{\varepsilon}+\mathrm{aO}_{2} \rightarrow \mathrm{bCO} \mathrm{CO}_{2}+\mathrm{c} \mathrm{H} \mathrm{H}_{2} \mathrm{O}+\mathrm{d} \mathrm{NO} \mathrm{NO}_{2}+\mathrm{eSO} \\
& \mathrm{C}_{\alpha} \mathrm{H}_{\beta} \mathrm{O}_{\gamma} \mathrm{N}_{\psi} \mathrm{S}_{\varepsilon} \rightarrow \mathrm{fH}_{2}+\mathrm{gCO}+\mathrm{h} \mathrm{CO}_{2}+\mathrm{i} \mathrm{H}_{2} \mathrm{O}+\mathrm{jCH}_{4}+\mathrm{k} \mathrm{C}_{2} \mathrm{H}_{4}+\mathrm{lCOS}+\mathrm{m} \mathrm{H}_{2} \mathrm{~S} \\
& +\mathrm{nNH}_{3}+\mathrm{p} \text { ORG + q CHARORG }
\end{aligned}
$$

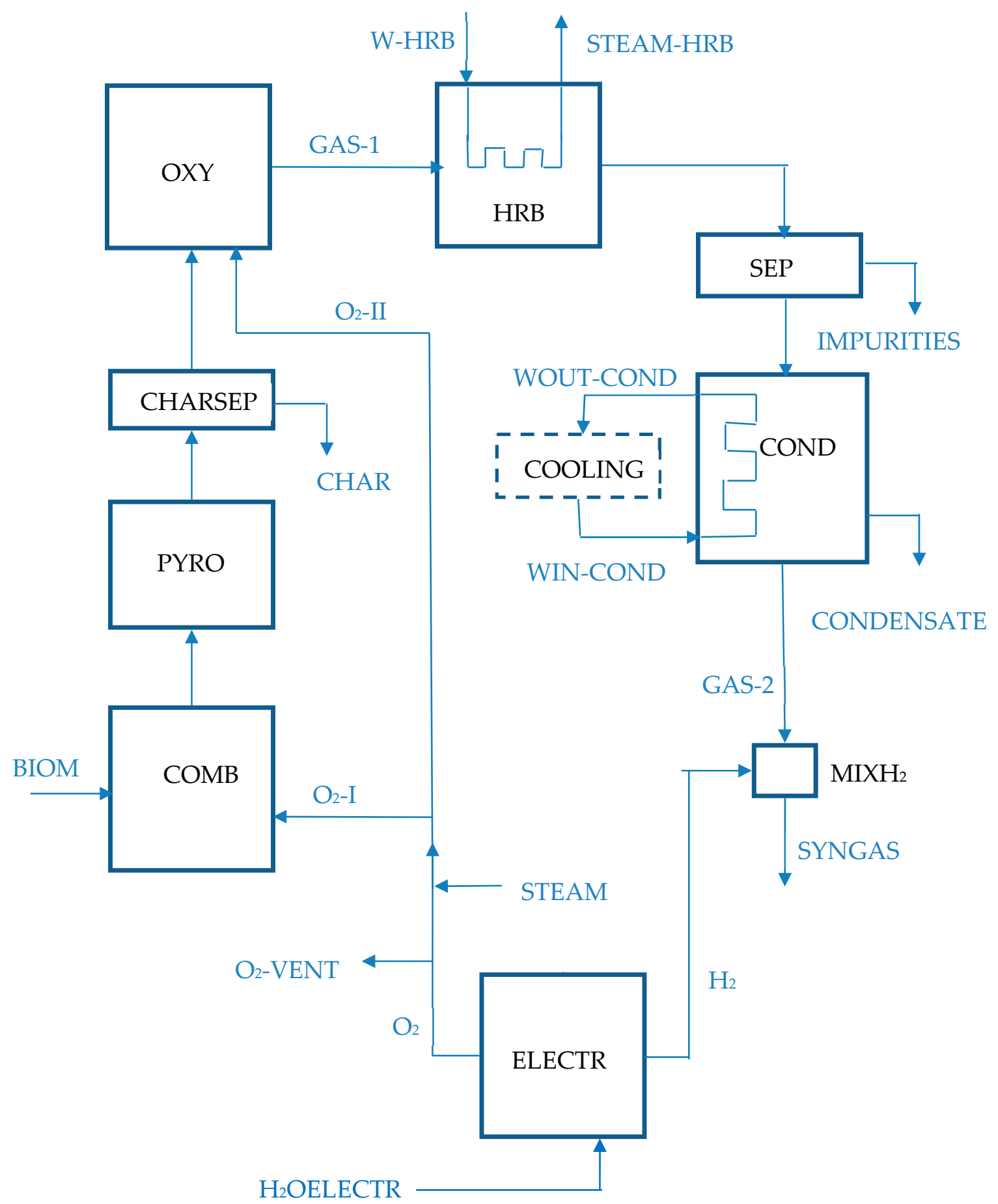

Figure 3. Block calculation diagram. 
Reaction (7) represents the partial oxidation of biomass to generate a gas mixture made of $\mathrm{CO}_{2}, \mathrm{H}_{2} \mathrm{O}$, nitrogen dioxide $\left(\mathrm{NO}_{2}\right)$, and sulphur dioxide $\left(\mathrm{SO}_{2}\right)$. Reaction (7) supplies the heat required for the pyrolysis process (Reaction (8)) to proceed. Reaction (8) models the pyrolysis process in which ORG represents any organic material (including tars, but excluding the char) coming out of the pyrolysis process, CHARORG represents the organic part of the solid carbonaceous material (the char) exiting the gasifier, $\mathrm{C}_{2} \mathrm{H}_{4}$ is ethylene, COS is carbonyl sulfide, $\mathrm{H}_{2} \mathrm{~S}$ is hydrogen sulfide, and $\mathrm{NH}_{3}$ is ammonia.

The CHAR stream exiting the gasifier contains an organic part (called CHARORG) along with the inert inorganic (called INORG) content of the biomass feed. Organics (ORG) and CHARORG are represented by the respective empirical formulas: $\mathrm{C}_{\alpha^{\prime}} \mathrm{H}_{\beta^{\prime}} \mathrm{O}_{\gamma^{\prime}} \mathrm{N}_{\psi^{\prime}} \mathrm{S}_{\mathcal{\varepsilon}^{\prime}}$ and $\mathrm{C}_{\alpha^{\prime \prime}} \mathrm{H}_{\beta^{\prime \prime}} \mathrm{O}_{\gamma^{\prime \prime}} \mathrm{N}_{\psi^{\prime \prime}} \mathrm{S}_{\varepsilon^{\prime \prime}}$. Table 1 lists the values of the coefficients used in the calculations, related to the composition of ORG, CHARORG, and the dry, ash-free biomass. Tables 2 and 3 show stoichiometric coefficients for Reactions (7) and (8), respectively. In Reaction (8), for the purpose of the calculations, the assumption is made that the pyrolysis of $1 \mathrm{~kg}$ of dry, ash-free biomass generates $0.18 \mathrm{~kg}$ of organic material (ORG) and $0.8 \mathrm{~kg}$ of CHARORG and that $20 \%$ of the carbon from the biomass is converted into $\mathrm{CO}_{2}, 15 \%$ into $\mathrm{CH}_{4}, 7.5 \%$ into $\mathrm{C}_{2} \mathrm{H}_{4}$, and $0 \%$ into COS.

Table 1. Values of coefficients $\alpha, \beta, \gamma, \psi$, and $\varepsilon$.

\begin{tabular}{cccc}
\hline & Biomass * (Dry, Ash Free) & ORG & CHAR \\
\hline$\alpha$ & 4.167 & 0.60 & 7.0833 \\
$\beta$ & 6.20 & 1.20 & 1 \\
$\gamma$ & 2.730625 & 0.60 & 0.875 \\
$\psi$ & 0.0071429 & 0 & 0 \\
$\varepsilon$ & 0.0003125 & 0 & 0 \\
\hline
\end{tabular}

* Dry, ash-free biomass is arbitrarily represented as an empirical molecule with a molecular weight of $100 \mathrm{~g} / \mathrm{mol}$ for the purpose of calculations. The char is modeled likewise.

Table 2. Stoichiometric coefficients for Reaction (7).

\begin{tabular}{ccccc}
\hline $\mathbf{O}_{2}$ & $\mathrm{CO}_{\mathbf{2}}$ & $\mathbf{H}_{\mathbf{2}} \mathbf{O}$ & $\mathbf{N O}_{2}$ & $\mathbf{S O}_{2}$ \\
\hline 4.3588 & 4.1667 & 3.100 & 0.0071429 & 0.003125 \\
\hline
\end{tabular}

Table 3. Stoichiometric coefficients for Reaction (8).

\begin{tabular}{ccccccccccc}
\hline $\mathbf{H}_{2}$ & $\mathrm{CO}$ & $\mathrm{CO}_{2}$ & $\mathbf{H}_{\mathbf{2}} \mathbf{O}$ & $\mathrm{CH}_{\mathbf{4}}$ & $\mathrm{C}_{\mathbf{2}} \mathbf{H}_{\mathbf{4}}$ & $\mathrm{COS}$ & $\mathbf{H}_{\mathbf{2}} \mathbf{S}$ & $\mathbf{N H}_{3}$ & $\mathrm{ORG}$ & $\mathrm{CHAR}$ \\
\hline 0.49293 & 0.27917 & 0.8333 & 0.036042 & 0.625 & 0.3125 & 0 & 0.00031250 .00714 & 0.10 & 0.17 \\
\hline
\end{tabular}

As shown in Figure 3, the gasifier is characterised by four mathematical blocks:

- COMB: Adiabatic, stoichiometric calculation of Reaction (7);

- PYR: Stoichiometric calculation of Reaction (8) assuming a heat loss of $100 \mathrm{~kW}$ is specified (1.8\% of the energy content of the biomass);

- CHARSEP: Separation of the organic part CHARORG from the inorganic components of the char that originate from the biomass;

- OXY: Calculation—using Gibbs free energy minimization algorithm—of the equilibrium composition after injection of $\mathrm{O}_{2} /$ steam mixture, assuming a heat loss of $150 \mathrm{~kW}$ ( $2.7 \%$ of the biomass energy content).

The first three blocks model Zone-I, as shown in Figure 1 (or standard gasifier in Figure 2), while the OXY block models Zone-II of the gasifier (tar conversion zone). The pressure is specified at 4 bars for these blocks, except for block OXY, in which pressure is specified at 3 bars. Streams of $\mathrm{O}_{2}$ injected in each of Zone I and Zone II, respectively $\mathrm{O}_{2}$-I and $\mathrm{O}_{2}$-II, contain $66.7 \mathrm{wt} \%$ of $\mathrm{O}_{2}$ and $33.3 \mathrm{wt} \%$ of steam. The flow rate of the $\mathrm{O}_{2}$ containing stream $\left(\mathrm{O}_{2}-\mathrm{I}\right)$ for block $\mathrm{COMB}$ is adjusted so that the temperature calculated for the PYR block is close to $800{ }^{\circ} \mathrm{C}$. The flow rate of the $\mathrm{O}_{2}$ containing stream $\left(\mathrm{O}_{2}\right.$-II) is 
adjusted so that the gas mixture in block OXY reaches a temperature near $1200^{\circ} \mathrm{C}$. This temperature is high enough for complete tar conversion, generating extra useful syngas molecules in the process.

Block HRB models the heat recovery boiler. This block allows for the calculation of heat exchanged for a fast cooling of the gas (GAS-1) exiting the gasifier down to $150^{\circ} \mathrm{C}$. The flow rate of the water stream (W) heated in block HRB is adjusted to obtain steam (STEAM) at a temperature close to $200{ }^{\circ} \mathrm{C}$ and pressure specified at 5 bars.

Block SEP is a simple calculation for a specific rate of separation of sulphur-based impurities and $\mathrm{NH}_{3}$. A separation ratio of $95 \%$ is assumed.

Block COND is a heat exchanger block calculation for the condensation of water in the syngas. The gas outlet temperature is specified at $40{ }^{\circ} \mathrm{C}$. The cooling water flow rate (CWIN-COND) is adjusted so that the cooling water outlet (WOUT-COND) is at a temperature lower than $95^{\circ} \mathrm{C}$. The cooling water inlet (WIN-COND) of the condenser is specified at a temperature of $30^{\circ} \mathrm{C}$ and a pressure of 5 bars.

Block MIXH2 is a simple mixing of the dehumidified syngas with the required amount of $\mathrm{H}_{2}$ to obtain the required balanced syngas with variable $\mathrm{M}$ from Equation (3) close to 2.0.

Block ELECTR is a simple stoichiometric calculator for Reaction (6). The amount of water fed is adjusted so that the correct amount of $\mathrm{H}_{2}$ required for syngas balancing is mixed at block MIXH2. Since the solid oxide electrolysis technology is used as the electrolysis system, H2OELECTR is a steam stream. A large part of this stream could come from steam exiting the HBR unit (STEAM-HRB).

\section{Results and Discussion}

Table 4 shows the main results. The system is fed with $1000 \mathrm{~kg} / \mathrm{h}$ of dry biomass with an LHV of $20 \mathrm{MJ} / \mathrm{kg}$. This biomass thus has an intrinsic thermal potential of $5555 \mathrm{~kW}$. Dry syngas is produced at a rate of $1295 \mathrm{~kg} / \mathrm{h}$ with an average molecular weight of $11.76 \mathrm{~g} / \mathrm{mol}$ and a calculated LHV of $2.12 \times 10^{8} \mathrm{~J} / \mathrm{kmol}$, which means $6487 \mathrm{~kW}$ of intrinsic thermal potential. The value of the $\mathrm{M}$ ratio calculated according to Equation (3), is 2.0. Carbon yield in the syngas is $75 \%$. The other $25 \%$ of carbon from biomass feed is assumed to be found within the $150 \mathrm{~kg} / \mathrm{h}$ of char produced.

Aside from the energy input contained in the biomass, the system also requires an energy input in the form of electricity powering the solid oxide electrolyser that generates the $\mathrm{H}_{2}$ and $\mathrm{O}_{2}$ streams. The electrolytic $\mathrm{H}_{2}$ required for the process is calculated at $115 \mathrm{~kg} / \mathrm{h}$, which means that $1035 \mathrm{~kg} / \mathrm{h}$ of $\mathrm{H}_{2} \mathrm{O}$ (as steam) is electrolysed. At the exit of the $\mathrm{HRB}, 1200 \mathrm{~kg} / \mathrm{h}$ of low-pressure steam is produced and could be used as a feed for the electrolysis block. In parallel, the electrolysis process produces $\mathrm{O}_{2}$ at a rate of $920 \mathrm{~kg} / \mathrm{h}$, which is greater than the overall $\mathrm{O}_{2}$ input flow rate of $480 \mathrm{~kg} / \mathrm{h}$ needed for the gasification process in Zones I and II. The unused, ultra-pure $\mathrm{O}_{2}$ could either be stored and sold or vented.

The LHV of $\mathrm{H}_{2}$ is $120 \mathrm{MJ} / \mathrm{kg}$. The assumption can be made that the electrolysis consumes $130 \mathrm{MJ} / \mathrm{kg}-\mathrm{H}_{2}$ or $36 \mathrm{kWh} / \mathrm{kg}-\mathrm{H}_{2}$. Producing $115 \mathrm{~kg} / \mathrm{h}$ of $\mathrm{H}_{2}$ requires electrical power consumption of $4140 \mathrm{~kW}$. The total system energy efficiency is represented by the following equation:

$$
\text { Efficiency }=\left(\mathrm{F}_{\text {syngas }}{ }^{*} \mathrm{LHV}_{\text {syngas }}\right) /\left(\mathrm{F}_{\text {Biom }}{ }^{*} \mathrm{LHV}_{\text {Biom }}+\text { Electr }\right)
$$

where $\mathrm{F}$ refers to the mass flow of a given stream, LHV refers to the lower heating value, and Electr is the electrical power used for electrolysis. Overall, a high total system energy efficiency value of $67 \%$ is obtained. All numerical results obtained through this simulation are not meant to present the most precise prediction possible of experimental results that would be obtained with a set-up since a great number of variables would influence these experimental results. In that regard, we can think of variables such as type/composition/humidity of biomass feed, temperature distribution, pressure, flow rate, particle size, type of gasifier (geometry, flow, residence time), and catalysts. The objective 
of this study is rather to obtain a general idea of what the proposed concept would lead to in terms of energy efficiency and improved carbon yield.

Table 4. Stream compositions, as calculated.

\begin{tabular}{|c|c|c|c|c|c|c|}
\hline Stream Name & BIOM & $\mathrm{O}_{2}-\mathrm{I}$ & $\mathrm{O}_{2}-\mathrm{II}$ & CHAR & GAS-1 & GAS-2 \\
\hline Temp $\left({ }^{\circ} \mathrm{C}\right)$ & 25 & 250 & 250 & 800 & 1224 & 50 \\
\hline Pres (bar) & 5 & 5 & 4 & 4 & 3 & 3 \\
\hline Total flow rate $(\mathrm{kg} / \mathrm{h})$ & 1055 & 300 & 420 & 145 & 1624 & 1128 \\
\hline \multicolumn{7}{|l|}{ Partial flow rates $(\mathrm{kg} / \mathrm{h})$} \\
\hline \multirow{2}{*}{\multicolumn{7}{|c|}{ ORGANICS }} \\
\hline & & & & & & \\
\hline \multicolumn{7}{|l|}{ CHARORG } \\
\hline Water & 50 & 100 & 140 & & 518.8 & 22.23 \\
\hline Oxygen & & 200 & 280 & & & \\
\hline Hydrogen & & & & & 35.36 & 35.36 \\
\hline Carbon monoxide & & & & & 541.7 & 541.7 \\
\hline Carbon dioxide & & & & & 527.5 & 527.5 \\
\hline Carbon oxysulfide & & & & & 0.009 & 0.0004 \\
\hline Hydrogen sulfide & & & & & 0.1004 & 0.005 \\
\hline Sulfur dioxide & & & & & 0.0004 & 0 \\
\hline Ammonia & & & & & 0.0006 & 0 \\
\hline Methane & & & & & 0.0004 & 0.0004 \\
\hline \multicolumn{7}{|l|}{ Ethylene } \\
\hline \multicolumn{7}{|l|}{ Ethane } \\
\hline Nitrogen & & & & & 0.9991 & 0.9991 \\
\hline \multicolumn{7}{|l|}{ Nitrogen oxide } \\
\hline \multicolumn{7}{|l|}{ Nitrogen dioxide } \\
\hline Inorganics & 5 & & & 5 & & \\
\hline \multicolumn{7}{|l|}{ Carbon } \\
\hline Stream Name & $\mathbf{H}_{2}$ & & & W-HRB & STE & HRB \\
\hline $\operatorname{Temp}\left({ }^{\circ} \mathrm{C}\right)$ & 137 & & & 50 & & \\
\hline Pres (bar) & 4 & & & 5 & & \\
\hline Total flow rate $(\mathrm{kg} / \mathrm{h})$ & 167 & & & 1200 & & \\
\hline \multicolumn{7}{|l|}{ Partial flow rates $(\mathrm{kg} / \mathrm{h})$} \\
\hline \multicolumn{7}{|l|}{ BIOM } \\
\hline \multicolumn{7}{|l|}{ ORGANICS } \\
\hline \multicolumn{7}{|l|}{ CHARORG } \\
\hline Water & 51.9 & & & 1200 & & \\
\hline \multicolumn{7}{|l|}{ Oxygen } \\
\hline Hydrogen & 115.2 & & & & & \\
\hline Carbon monoxide & & & & & & \\
\hline Carbon dioxide & & & & & & \\
\hline Carbon oxysulfide & & & & & & \\
\hline Hydrogen sulfide & & & & & & \\
\hline \multicolumn{7}{|l|}{ Sulfur dioxide } \\
\hline \multicolumn{7}{|l|}{ Ammonia } \\
\hline Methane & & & & & & \\
\hline \multicolumn{7}{|l|}{ Ethylene } \\
\hline \multicolumn{7}{|l|}{ Ethane } \\
\hline Nitrogen & & & & & & \\
\hline \multicolumn{7}{|l|}{ Nitrogen oxide } \\
\hline \multicolumn{7}{|l|}{ Nitrogen dioxide } \\
\hline \multicolumn{7}{|l|}{ Inorganic material } \\
\hline Carbon & & & & & & \\
\hline
\end{tabular}

The proposed technology contributes to the reduction of greenhouse gas emissions compared to other systems in a number of ways. Since the carbon contained in the biomass is biogenic, its release does not add any additional carbon that is not already in the earth's natural carbon cycle, unlike when methanol is produced from fossil fuel. Even if some carbon is released as $\mathrm{CO}_{2}$ during the synthesis process or as part of a subsequent methanol combustion application, the greenhouse effect from this emission would be much less severe than that from $\mathrm{CH}_{4}$ that would otherwise be released from wood waste if it were left decaying in nature instead of used as an entrant in the system. The injection of green, electrolytic $\mathrm{H}_{2}$ into the process has the additional effect of lowering drastically the amount of $\mathrm{CO}_{2}$ that would otherwise be rejected by the process. Finally, the regional concept 
for these production plants means shorter methanol transportation distances, along with smaller $\mathrm{CO}_{2}$ quantities generated during this transportation.

\section{Conclusions and Outlook}

A simple concept was presented, which comprised a gasifier and a high-temperature electrolyser working in tandem to produce balanced syngas. This syngas has the right composition to be used in methanol synthesis. With calculations based on mass and energy balance, along with stoichiometry and thermodynamic equilibrium calculations, such a tandem was shown to achieve superior carbon conversion yield (75\%) and overall energy efficiency $(67 \%)$. This approach of producing syngas from wood is much more efficient and productive than relying only on gasification followed by a water-gas shift reaction in order to increase the $\mathrm{H}_{2} / \mathrm{CO}$ ratio since this reaction involves a significant loss of carbon as $\mathrm{CO}_{2}$. The system presented here would be especially environmentally sustainable if renewable electricity is utilised.

Behind the concept presented here is the idea of using small plants for decentralised production of a platform molecule such as methanol, a molecule that can be easily produced with syngas based on $\mathrm{H}_{2}, \mathrm{CO}$, and also $\mathrm{CO}_{2}$. In turn, methanol could be distributed for various applications, including the production of other molecules. A feed material such as wood pellets could be produced nearby as a local biomass resource and transported towards a small regional methanol plant that serves a regional market with lower transportation costs and risks. In addition, applying this concept to small plants means less financial hurdle per plant project and less time to complete each project.

For these small plants, a simple design gasifier similar to the one presented here is well suited. Given the highly energy-efficient process presented here, the outlook for this application of the solid oxide electrolyser technology appears to be a very promising one because this equipment has the dual function of providing all of the supplemental $\mathrm{H}_{2}$ required for syngas balancing, in addition to all the $\mathrm{O}_{2}$ required for the production of well reformed hot raw syngas.

Author Contributions: Conceptualization, S.L. and R.L.; methodology, R.L.; software, R.L.; validation, S.L., R.L. and P.M.; formal analysis, S.L. and R.L.; data curation, R.L.; writing-original draft preparation, S.L. and R.L.; writing-review and editing, S.L and R.L.; visualization, S.L. and R.L.; supervision, P.M.; project administration, P.M.; funding acquisition, S.L. All authors have read and agreed to the published version of the manuscript.

Funding: This research received no external funding.

Data Availability Statement: Data from simulations has been archived by R.L.

Acknowledgments: The authors gratefully acknowledge internal financing from the Université du Québec à Trois-Rivières (for associate professors (SL)) and Hydro-Québec.

Conflicts of Interest: The authors declare no conflict of interest.

\section{References}

1. Philp, R.J. Methanol Production from Biomass; National Research Council of Canada: Ottawa, ON, Canada, 1986.

2. Vertès, A.A.; Qureshi, N.; Blaschek, H.P.; Yakuwa, H. (Eds.) Biomass to Biofuels—Strategies for Global Industries; Wiley: Hoboken, NJ, USA, 2010.

3. Ali, S.; Sorensen, K.; Nielsen, M.P. Modeling a novel combined solid oxide electrolysis cell (SOEC)—Biomass gasification renewabl methanol production system. Renew. Energy 2020, 154, 1025-1034. [CrossRef]

4. Jahromi, R.; Rezaei, M.; Samadi, S.H.; Jahromi, H. Biomass gasification in a downdraft fixed-bed gasifier: Optimization of operating conditions. Chem. Eng. Sci. 2021, 231, 116249. [CrossRef]

5. Dong, K.; Rong, Q.; Li, M.; Lin, J.; Xiao, R.; Li, Y. A novel simulation for gasification of Shenmu Coal in an entrained flow gasifier. Chem. Eng. Res. Des. 2020, 160, 454-464. [CrossRef]

6. Olatunji, O.; Akinlabi, S.; Madushele, N. Application of Artificial Intelligence in the Prediction of Thermal Properties of Biomass. Valorization of Biomass to Value-Added Commodities. In Valorization of Biomass to Value-Added Commodities: Current Trends, Challenges, and Future Prospects; Michael, O., Daramola, A., Ayeni, O., Eds.; Springer: Berlin/Heidelberg, Germany, 2020; Chapter 4 ; pp. 59-91. 
7. Stuart, P.R.; El-Halwagi, M.H. (Eds.) Integrated Biorefineries-Design, Analysis, and Optimization; CRC Press: Boca Raton, FL, USA, 2013.

8. Rechenauer, C.; Achenbach, E. Dreidimensionale Mathematische Modellierung des Stationä ren und Instationä ren Verhaltens Oxidkeramischer HochtemperaturBrennstoffzellen; RWTH Aachen: Julich, Germany, 1992.

9. Teislev, B. Harboore-woodchips gasifier and $1500 \mathrm{~kW}$ gas engines operating at $32 \%$ power efficiency in CHP configuration. In Proceedings of the 12th European Conference on Biomass, Amsterdan, The Netherlands, 17-21 June 2002.

10. Wang, D.; Montane, D.; Chornet, E. Catalytic steam reforming of biomass-derived oxygenates: Acetic acid and hydroxyacetaldehyde. Appl. Catal. A Gen. 1996, 143, 245-270. [CrossRef]

11. Salema, A.M.; Zaini, I.N.; Paul, M.C.; Yang, W. The evolution and formation of tar species in a downdraft gasifier: Numerical modelling and experimental validation. Biomass Bioenergy 2019, 130, 105377. [CrossRef]

12. Nam, H.; Rodriguez-Alejandro, D.A.; Adhikari, S.; Brodbeck, C.; Taylor, S.; Johnson, J. Experimental investigation of hardwood air gasification in a pilot scale bubbling fluidized bed reactor and CFD simulation of jet/grid and pressure conditions. Energy Convers. Manag. 2018, 168, 599-610. [CrossRef]

13. Harboøre, V. Denmark Wood Chips Gasification CHP Plant, Babcock \& Wilcox Vølund A/S. Available online: http://www. volund.dk/Biomass_energy/References/Harboore (accessed on 16 July 2020).

14. Pandiyan, A.; Uthayakumar, A.; Subrayan, R.; Cha, S.K.; Moorthy, S.B.K. Review of solid oxide electrolysis cells: A clean energy strategy for $\mathrm{H}_{2}$ generation. Nanomater. Energy 2019, 8, 2-22. [CrossRef] 